\title{
Gaseous and Particulate Matter Emissions from Road Transport: The Case of Kolkata, India
}

\author{
Abhishek DUTTA ${ }^{1}$, Wanida JINSART ${ }^{2 *}$ \\ ${ }^{1,2}$ Department of Environmental Science, Faculty of Science, Chulalongkorn University, 254 Phayathai \\ Road, Pathumwan, Bangkok 10330, Thailand
}

\begin{abstract}
Indian cities are highly dependent on road transport for freight and passenger traffic movements. The estimated road transport led yearly emission inventory of pollutants for 25 million-plus population cities of India indicates vehicle stock as the critical contributor to air pollution in cities. During 2025 the city of Kolkata will be responsible for the emission of $21668.24 \mathrm{Gg}$ of $\mathrm{CO}_{2}$ followed by $272.81 \mathrm{Gg}$ of $\mathrm{CO}, 98.21 \mathrm{Gg}$ of $\mathrm{NO}_{\mathrm{x}}, 16.9 \mathrm{Gg} \mathrm{of} \mathrm{CH}_{4}$, 93.39 Gg of $\mathrm{SO}_{2}, 8.6 \mathrm{Gg}$ of $\mathrm{PM}$, and 38.55 Gg of $\mathrm{HC}$ due to its 2.79 million vehicles. The total vehicle stock of 25 leading Indian cities increased by $19 \%$ during 2015-2017, and during the same period, Rajkot and Vadodara had the highest rise of $97 \%$ and $94 \%$ respectively. Out of 25 cities total $\mathrm{CO}_{2}(220560 \mathrm{Gg})$ and $\mathrm{CO}(3185 \mathrm{Gg})$ vehicular emissions during 2017, Delhi was the highest contributor with $22 \%$ and $20 \%$ respectively followed by Bengaluru (12\%, $12 \%$ ), and Chennai ( $9 \%, 8 \%)$. The GHG emission per unit area of Kolkata during 2017, due to on-road vehicular emission, was the highest amongst the 25 cities of India. For Kolkata, cars were responsible for $35 \%$ for $\mathrm{CO}_{2}, 55 \%$ of $\mathrm{CO}, 75 \%$ of $\mathrm{CH}_{4}, 27 \%$ of $\mathrm{PM}$, omnibuses for $41 \%$ for $\mathrm{NO}_{\mathrm{x}}$ emission, taxis for $83 \%$ of $\mathrm{SO}_{2}$, and two-wheelers for $36 \%$ of $\mathrm{HC}$ emissions.
\end{abstract}

Keywords - Air pollution; emission inventory; GHG emission per unit area; Indian cities; motor vehicle emission

\section{INTRODUCTION}

Kolkata city, the erstwhile capital of the British Indian Empire, is a fast-growing metropolis now where along with the growth of population and economic activities, the level of air pollution is also increasing significantly [1]. Recent research, covering 109 Indian cities, has put Kolkata under the severely vulnerable tag due to the higher status of ambient particulate matter of diameter less than or equal to 2.5 micrometres $\left(\mathrm{PM}_{2.5}\right)$ and thereby indicating the urgency on prioritizing a clean-air action plan for the city at the earliest [2]. The World Health Organisation (WHO) report covering 4000 cities of 100 countries for the year 2016, released during June 2018, revealed that Kolkata was only second after Delhi in terms of highly polluted cities of India. The air quality of Kolkata worsened more rapidly than that of Delhi [3]. The Central Pollution Control Board (CPCB) of India also expressed concern about the faster deterioration of air quality of Kolkata which is the most important city of eastern India in terms of economic reasons [4].

Indian cities, in general, are characterized by the high motor vehicle population as they are excessively dependent on their road network for freight and passenger traffic movements. The World Bank [5] estimated that about $60 \%$ of freight and $85 \%$ of passenger traffic movements usually depend on on-road transportation only in India. Accordingly, cities are

\footnotetext{
*Corresponding author.

E-mail address: jwanida@chula.ac.th 
overly reliant on on-road transportation, and the majority of motor vehicles are running with diesel and petrol as clean fuel like compressed natural gas (CNG) is yet to be available in most of the cities [6]. Indian cities are now accommodating $35 \%$ of India's massive population and at the same time, contributing to about $69 \%$ of its gross domestic product [7], [8]. The motor vehicle stock in Indian cities has grown steadily in the past. It is expected to continue with the momentum in the future due to the increase in population, migration, and economic growth [9], [10]. The researchers indicated that transport sectors played a significant role in polluting the environment in Indian cities [11]-[13]. The road transport was found alone responsible for $94.5 \%$ and $53.3 \%$ of carbon dioxide $\left(\mathrm{CO}_{2}\right)$ and carbon monoxide (CO) emission, respectively, in India [14]. The transport sector contributed most of the oxides of nitrogen $\left(\mathrm{NO}_{\mathrm{X}}\right), \mathrm{CO}$, and non-methane volatile organic compound (NMVOC) emissions in the capital city of Delhi [15]. The vehicular emission concentrations in Indian cities are significant and require policymakers' attention [16]. The vehicular emissions are not only pronounced in big cities, but smaller cities are also equally affected [17]. Although the respective local government has been trying to phase out old automobiles, still the cities are housing an abundance of poorly maintained old motor vehicles.

At the city level, there exists a mismatch between the official and actual size of the vehicle stock, which influences vehicular emission estimations [18], [19]. The two-wheelers and diesel automobiles are increasing in cities and are the major contributors to air pollution [20], [21]. The intra-city buses for travel across cities are significantly contributing to pollutants during peak periods [22]. The various control measures enacted by the regulatory authorities of Delhi failed to curb the $\mathrm{NO}_{\mathrm{x}}$ emissions from automobiles [23]. The cities required controlling the ever-increasing population of two-stroke two-wheelers for reducing the emission of hydrocarbon compounds $(\mathrm{HC})$, carbon dioxide $\left(\mathrm{CO}_{2}\right)$, and $\mathrm{CO}$ in India [24]. Researchers advocated phasing out of old automobiles, rigorous periodic pollution tests, and better technology in terms of fuel combustion as the solutions for vehicular emission problems in India [25]-[27]. Stricter policy-led norms and fast adaptation of CNG as fuel by the public transport automobiles are the need of the hour [28].

Indian environment watchdog, National Green Tribunal (NGT) has recently reprimanded CPCB for the rapidly deteriorating ambient air quality of Indian cities [29]. A city like Kolkata has reached threatening dimensions in terms of air pollution in Kolkata because of the ever-increasing two-wheelers population, the predominance of older vehicles, high vehicle density, bad road conditions, and the absence of a mass traffic system [30]. A comparatively recent study highlighted extremely high PM concentrations $\left(\mathrm{PM}_{10}=445\right.$ $\mu \mathrm{g} \mathrm{m}^{-3}$ and $\mathrm{PM}_{2.5}=313 \mu \mathrm{g} \mathrm{m}^{-3}$ ) during the winter months in Greater Kolkata [31].

Against this background, this study has built up greenhouse gas (GHG) inventory for the city of Kolkata due to its road transport sector following a bottom-up approach. The total emissions have been worked out by summing every vehicle's emission and compared the same with other leading cities of the country. In the Indian city context, the bottom-up approach has been used to develop emission inventories for the road transport sector for different states as well as for a specific city like Delhi [14], [20], [32]. The present study differs from them in the following ways. First, it estimated the road transport led emission load of Kolkata up to 2025 based on the projected automobile population of the city. Second, it estimates city-wise road transport led inventory of GHG emissions across 25 leading million plus populated cities for the years 2015-2017, including Kolkata. Third, it computed and compared GHG emissions per unit area of the 25 cities for the years 2015-2017 to understand the variations of emissions across leading cities of the country from the road 
transport sector. Finally, emissions due to different types of road transport vehicles have been compared across five Indian metropolitan cities, including Kolkata for the year 2017.

\section{LOCATION OF STUDY}

Kolkata city is the capital of the state of West Bengal (Fig. 1). As per the 2011 population census, Kolkata ranked third amongst the cities of India in terms of population and has a high population density (persons per sq. $\mathrm{km}$ ) of 24306 . The city is on the eastern bank of the river Ganges and the Bay of Bengal is about $120 \mathrm{~km}$ away from the city. Kolkata has a tropical wet and dry climate with an annual mean temperature of $26.8^{\circ} \mathrm{C}$. The city experiences three seasons, summer, monsoon, and a short winter of about two months with temperature $9-23{ }^{\circ} \mathrm{C}$ range [33]. Summer is a long season with daily temperatures ranging from $27-38{ }^{\circ} \mathrm{C}$. Rainy weather starts from mid of June when the south-west monsoon rich with moisture gathered from the Bay of Bengal flows over the city and continues till the end of September. The minimal geographic expansion, high population density, traffic congestion, poverty, and increasing vehicle stock make Kolkata an ideal city for a case study of air pollution caused by its road transport sector [31]. The 2011 census of India indicated 53 urban agglomerations in the country with a human population of 1 million or more. Out of them, 25 leading millionplus Indian cities have been considered in this study (Fig. 1) for road transport led annual emission inventory estimation which includes top-five metropolitan cities of the county like Mumbai, Delhi, Kolkata, Chennai, and Bengaluru [34].
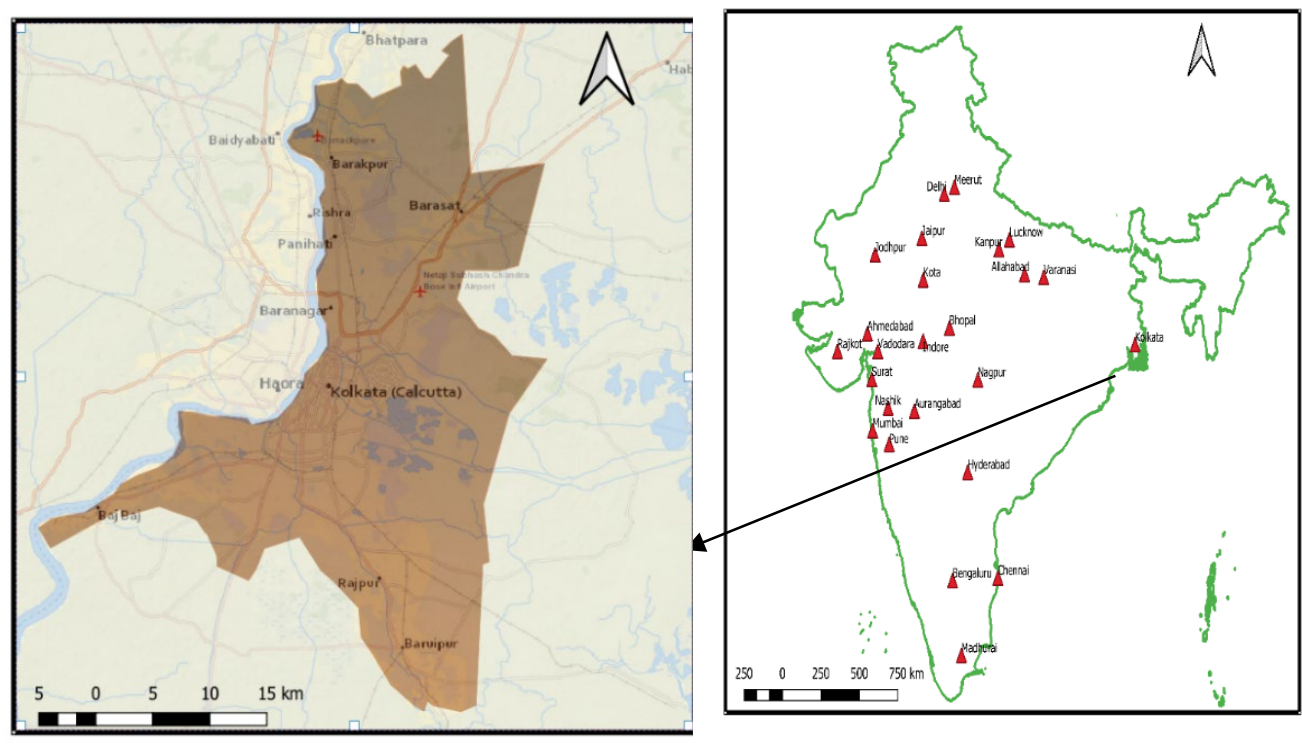

Fig. 1. Kolkata and 24 other million-plus Indian cities.

\section{Methodology}

In general pollutants and gases like particulate matter $(\mathrm{PM})$, carbon monoxide $(\mathrm{CO})$, carbon dioxide $\left(\mathrm{CO}_{2}\right)$, nitrogen oxides $\left(\mathrm{NO}_{\mathrm{x}}\right)$, nitrous oxide $\left(\mathrm{N}_{2} \mathrm{O}\right)$, sulphur dioxide $\left(\mathrm{SO}_{2}\right)$, methane $\left(\mathrm{CH}_{4}\right)$, non-methane volatile organic compounds (NMVOC), and hydrocarbon (HC) are 
associated with the vehicular exhaust. Depending upon the type of engine, fuel used, vehicle age, and condition of using the emissions from vehicles vary. Road transport is a critical contributor to air pollution in the Indian city context because of excess use of diesel as fuel and non-availability of environment-friendly fuel like $\mathrm{CNG}$ gas in many Indian cities including Kolkata.

\subsection{Assessment of Motor Vehicle Population and Projection}

The category-wise motor vehicle population data of Kolkata, for twelve years (2006-2017) were collected from the Indiastat [35] and Open Government Data (OGD) platform of the Government of India [36]. The category-wise motor vehicle population data of 24 other million-plus cities, for three years (2015-2017), also collected from the same sources. The online sources reported data in two broad categories, i.e., transport and non-transport. The transport category includes multi-axle/articulated, vehicles like trucks \& lorries (TL), light motor vehicles (goods) or LMVG, buses, taxis, light motor vehicles, (passenger) or LMVP. The non-transport category includes two-wheelers (TW), cars, jeeps, omnibuses, tractors, trailers, and other miscellaneous vehicles. The two-wheelers were then subdivided into TW motorcycles (4-Stroke TW or 4S-2W) and TW scooters (2-Stroke TW or 2S-2W). Indiastat and OGD data of TW do not provide the population of $4 \mathrm{~S}-2 \mathrm{~W}$ and $2 \mathrm{~S}-2 \mathrm{~W}$ separately. The proportion of $4 \mathrm{~S}-2 \mathrm{~W}$ and $2 \mathrm{~S}-2 \mathrm{~W}$ out of the total of TW was taken as $72: 28$ based on MoRTH report [37]. We used future growth forecasting techniques like the compound annual growth rate (CAGR) of respective category vehicles for the period 2006-2016 of Kolkata in projecting the total motor vehicle population of the city up to the year 2025 .

\subsection{Calculation of Emission Load}

In order to calculate the emission load due to road transport for the period 2015-2025, this study has used the following IPCC equation, Eq. 1 [38].

$$
E_{i}=\sum\left(V e h_{j} \cdot D_{j}\right) \cdot E F_{i, j, k m},
$$

where

$E_{i} \quad$ Total emissions load $(i)$;

$V e h_{j} \quad$ Number of different types of city vehicles $(j)$;

$D_{j} \quad$ Kilometer traveled/vehicles/year $(j) \mathrm{km}$;

$E F_{i, j, k m} \quad$ Emission of pollutants $(i)$ from vehicle type $(j)$ per travelled kilometre.

We used the motor vehicle utilization rate (average kilometre travelled per year) in India from the CPCB study [39]. The CPCB study found out the vehicle utilization rate based on a primary survey of six Indian cities. This study used the average utilization rates of different types of automobiles to reflect pan India status. Annual average kilometre travelled for TW(4S-2W), TW(2S-2W), car, car CNG, jeep petrol, omnibus, truck lorries, bus (diesel) and CNG taxi were 15 756, 13 444, 62 963, 62 963, 62 963, 41 914, 24 333, 41 914, and 62963 kilometres, respectively. Similarly, for LMVP, tractor, trailer, and LMVG were 29333 , 21000,63000 kilometres per year, respectively [40].

\subsection{Quantification of Emission Factors}

The Automotive Research Association of India, ARAI [41] undertook a pioneering attempt during 2007 to develop the emission factors for automobiles plying on the Indian road. This project aimed at the development of typical values of pollutants emitted by different types of automobiles to the atmosphere. The automobiles of five different generations (viz, 1991-96, 
1996-2000, post-2000, and post 2005) were considered for understanding the relationship between technology and emission factors and after that use of the relationships to indicate the emission factors for automobiles plying on Indian roads. Different researchers in the field, as well as agencies from time to time, contributed to further update the emission factors as applicable in India. Emission factors, usually expressed in gram per kilometre (gm per km), depends on various factors like actual driving condition, road unevenness, the laden weight of the automobile, acceleration or de-acceleration, vehicle age, fuel condition, ambient temperature, and vehicle maintenance. It is not possible to have a pan world standardized emission inventory as the ground conditions are different. Different pieces of the literature on the even subject also used these emission factors for different types of automobiles plying in the country. It is challenging to have the exact break up of different types of two-wheelers plying on the road, so in the case of two-wheelers, the average of emission factors $(4 \mathrm{~S}-2 \mathrm{~W}$ and $2 \mathrm{~S}-2 \mathrm{~W}$ ) have been considered for generalization. The emission factors of different types of vehicles in India considered for this study can be seen in Table 1.

TABLE 1. EMISSION FACTORS OF DIFFERENT TYPES OF AUTOMOBILES IN INDIA IN GM KM ${ }^{-1}$

\begin{tabular}{llllllll}
\hline Vehicle type & $\mathbf{C O}_{2}$ & $\mathbf{C O}$ & $\mathbf{N O}_{\mathbf{x}}$ & $\mathbf{C H}_{\mathbf{4}}$ & $\mathbf{S O}_{2}$ & $\mathbf{P M}$ & $\mathbf{H C}$ \\
\hline Truck, Lorries & 515.2 & 3.6 & 6.3 & 0.09 & 1.42 & 0.28 & 0.87 \\
LMVG \& LMVP & 60.3 & 5.1 & 1.28 & 0.18 & 0.029 & 0.2 & 0.14 \\
Buses & 515.2 & 3.6 & 12 & 0.09 & 1.42 & 0.56 & 0.87 \\
Taxis & 208.3 & 0.9 & 0.5 & 0.01 & 10.3 & 0.07 & 0.13 \\
2S-2W & 26.58 & 1.37 & 0.2 & 0.18 & 0.023 & 0.045 & 2.53 \\
4S-2W & 26.95 & 4.47 & 0.61 & 0.18 & 0.023 & 0.011 & 1.57 \\
Car & 223.6 & 1.98 & 0.2 & 0.17 & 0.053 & 0.03 & 0.25 \\
Jeep & 223.6 & 1.98 & 0.2 & 0.17 & 0.053 & 0.03 & 0.25 \\
Omnibuses & 515.2 & 3.6 & 12 & 0.09 & 1.42 & 0.56 & 0.87 \\
Tractor & 515.2 & 5.1 & 1.28 & 0.09 & 1.42 & 0.2 & 0.14 \\
Trailer & 515.2 & 5.1 & 1.28 & 0.09 & 1.42 & 0.2 & 0.14 \\
Others & 343.87 & 3.86 & 3.89 & 0.11 & 1.94 & 0.24 & 0.54 \\
\hline
\end{tabular}

Note: The emission factors have been taken from [14], [42]-[48].

\subsection{Calculation of Road Transport Emission of Cities}

Measurement and quantifications of city-level road transport emission, both city-wise total emission and per unit area wise emissions, is essential in order to understand the pollution contribution and effect changes in technologies in emission parameters [14]. Emissions of primary pollutants $\left(\mathrm{PM}, \mathrm{CO}, \mathrm{CO}_{2}, \mathrm{NO}_{\mathrm{x}}, \mathrm{SO}_{2}, \mathrm{CH}_{4}\right.$, and $\mathrm{HC}$ ) by road transport during $2017-$ 2025 for Kolkata and during 2015-2017 for other 24 Indian cities were calculated out using the IPCC equation for different category of vehicles following their respective India specific mass emission factors [38]. The GHG gas emissions per unit of the geographical area-wise, expressed in gigagrams $(\mathrm{Gg})$ or megagrams $(\mathrm{Mg})$, for all the 25 cities for the period 2015 2017 was then calculated to assess emission intensity per unit city area by using Eq. (2):

$$
\text { Emission per unit area of city } \left.=\frac{\sum\left(\text { Emission }_{i j}\right)}{\text { Area }_{i}} \text { (in } \mathrm{Gg} \text { or } \mathrm{Mg} \mathrm{km}^{-2}\right) \text {, }
$$


where Area $_{i}=$ geographical area of municipal administration of the $i^{\text {th }}$ city $\left(\mathrm{km}^{2}\right)$ and $j^{\text {th }}$ type of vehicle. The geographical area of the cities was collected from respective city municipality websites.

Vehicle type-wise emission analyses were also carried out for five major Indian metropolitan cities using the IPCC equation for the year 2017, including Kolkata, to understand the contribution of dominant sources of emission in the total emissions of the cities in comparative terms.

\section{ReSUlts AND DisCUSSION}

\subsection{Vehicle Population for Kolkata}

Fig. 2 and depict the status of registered vehicles in the city of Kolkata both for the period 2006-2017 (actual) and 2018-2025 (projected). The registered automobiles increased from a mere 0.9 million to 1.71 million during 2006-2017 in Kolkata, with a steady rate of increase of $84 \%$. During this period, excepting for the tractor, trailer, and jeep category of automobiles, all other categories registered a definite increase. The projected vehicle stock, category wise, between 2018 and 2025 indicates that Kolkata will be the abode of about 2.79 million vehicles by 2025. During 2016-2017, LMVG registered highest rise in number (240\% followed by LMVP (132\%), taxi (129\%), omnibus $(114 \%)$, car $(107 \%)$, 4S-2W $(79 \%)$ and $2 \mathrm{~S}-2 \mathrm{~W}(79 \%)$. A personalized vehicle like cars accounted for more than $39 \%$ ( 0.67 million out of 1.71 million) of the total vehicle population of the city during 2017 . If other personalized vehicles like TW (4S-2W and $2 \mathrm{~S}-2 \mathrm{~W})$ are considered, then car and TW accounted for the major share, i.e., about $83 \%$ of the total vehicle population of Kolkata during the year 2017. There will be mammoth 1.15 million personalized cars plying on the roads of the city which would account for about $41 \%$ of the total during 2025 . Another major contributor $(40 \%)$ of total vehicles on the road by 2025 would be two-wheelers. Therefore, personalized cars and two-wheelers together would account for the bulk of the vehicle population $(81 \%)$ of the city during 2025 .

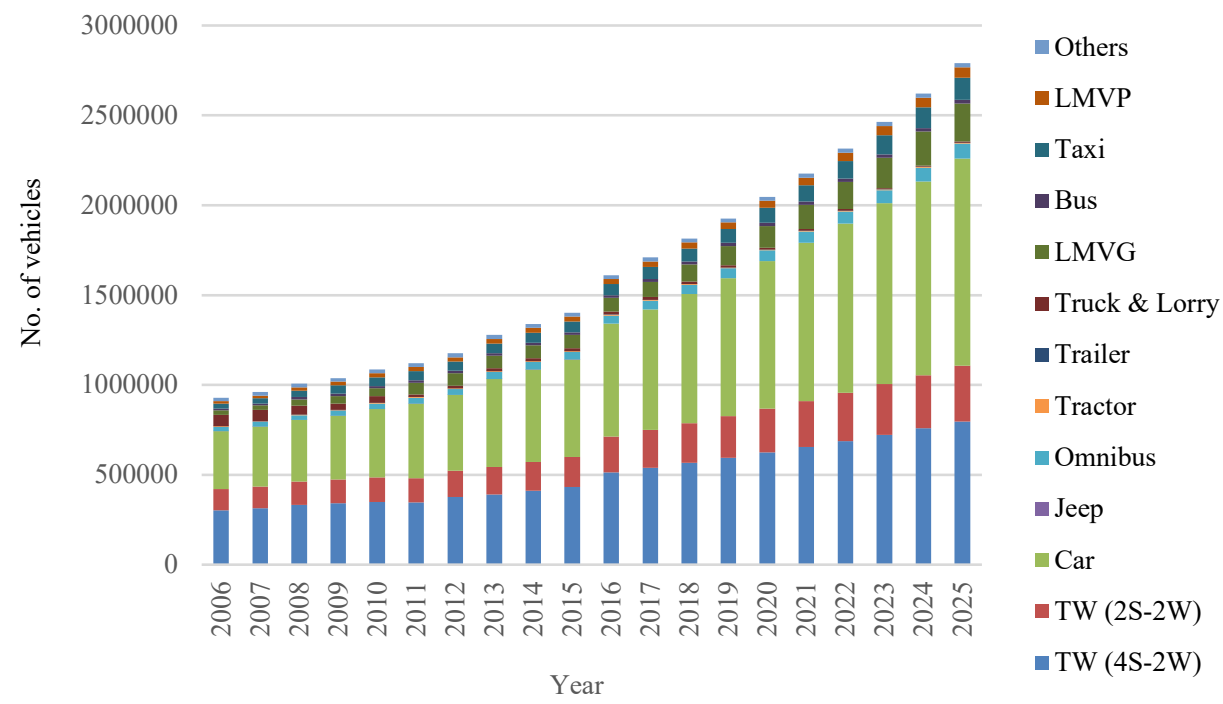

Fig. 2. Vehicle population in Kolkata (2006-2025). 


\subsection{Vehicular Emission in Kolkata}

The emissions of $\mathrm{PM}, \mathrm{CO}, \mathrm{CO}_{2}, \mathrm{NO}_{x}, \mathrm{SO}_{2}, \mathrm{CH}_{4}$, and $\mathrm{HC}$ during 2015-2025, for different vehicle categories in respect of Kolkata city, have been calculated out using IPCC, 2006 equation. The rising trend of annual emission of $\mathrm{CO}_{2}$ in Kolkata from 2015-2025 can be seen in Fig. 3A. The emission of $\mathrm{CO}_{2}$ will be $21668.24 \mathrm{Gg}$ during 2025 in India, which is about $104 \%$ more than the 2015 value of $10603.14 \mathrm{Gg}$. The increase in $\mathrm{CO}_{2}$ can be attributed mainly to a $107 \%$ increase in the total number of cars during the period 2015-2025. Cars alone will be responsible for about 75 of the total $\mathrm{CO}_{2}$ emission during 2025, followed by other types of automobiles like omnibuses (8\%), taxi $(7.6 \%)$, and LMVG (3\%).

$$
\mathrm{CO}_{2} \text { emission, Kolkata (2015-2025), Gg }
$$

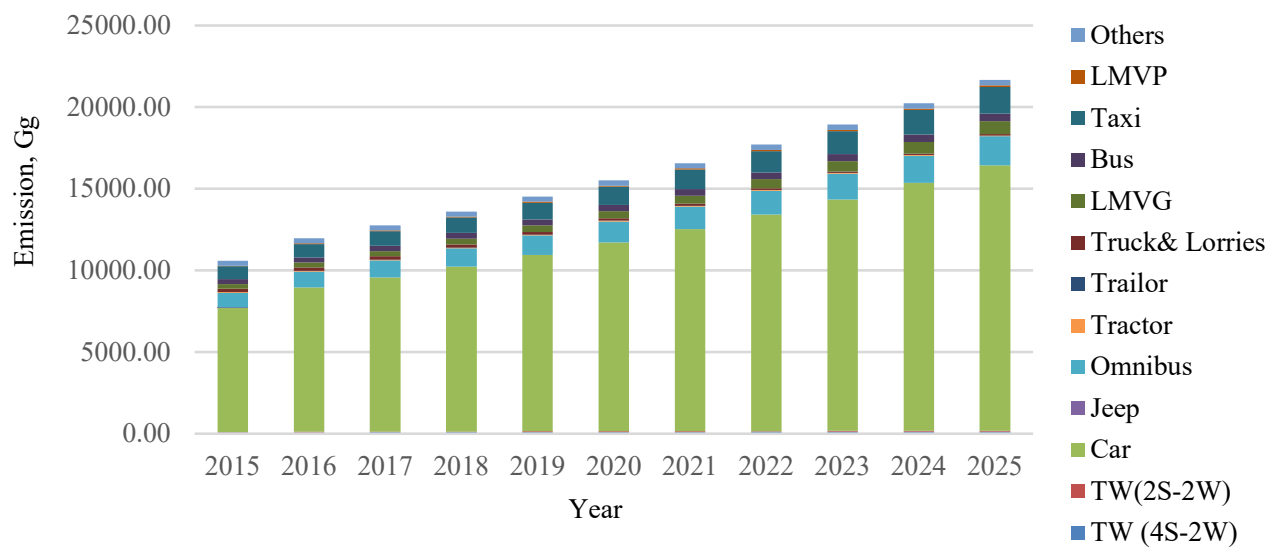

CO emission, Kolkata (2015-2025), Gg (b)

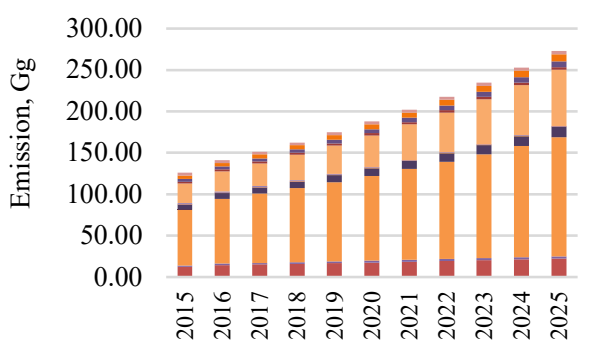

Year

\begin{tabular}{|c|c|c|}
\hline - TW (4S-2W) & $\square \mathrm{TW}(2 \mathrm{~S}-2 \mathrm{~W})$ & - Car \\
\hline - Jeep & -Omnibus & - Tractor \\
\hline - Trailor & - Truck\& Lorries & LMVG \\
\hline Bus & - Taxi & " LMVP \\
\hline
\end{tabular}

NOx emission, Kolkata (2015-2025), Gg

(c) 150.00

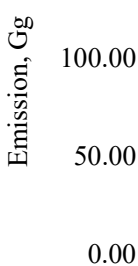

0.00

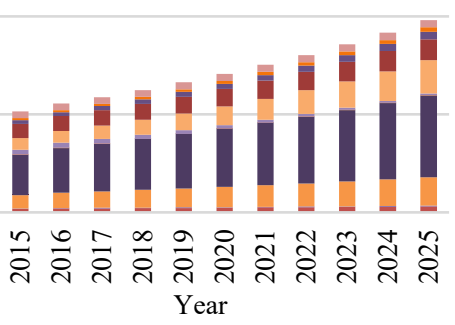

- TW (4S-2W)

- Car

- Omnibus

- Trailor

LMVG
TW(2S-2W)

Jeep

Tractor

- Truck\& Lorries

Bus 


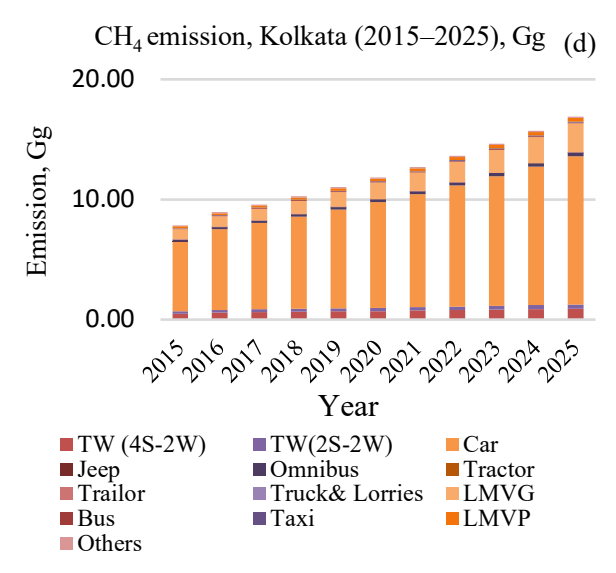

PM Emission, Kolkata (2015-2025), Gg

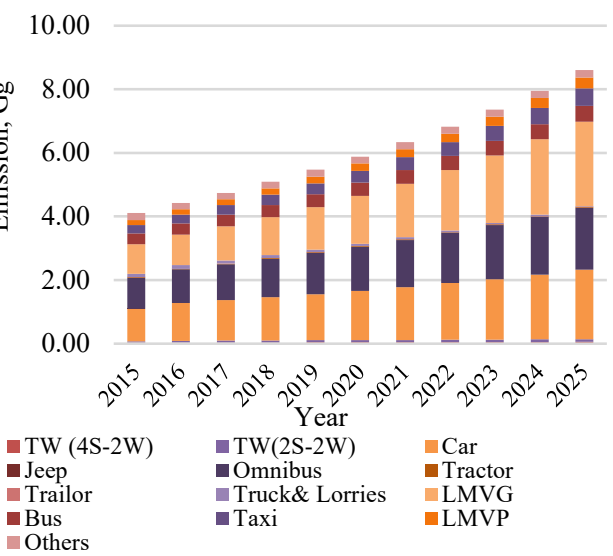

$\mathrm{CH}_{4}$ emission, Kolkata (2015-2025), (e)
$20.00 \quad \mathrm{Gg}$

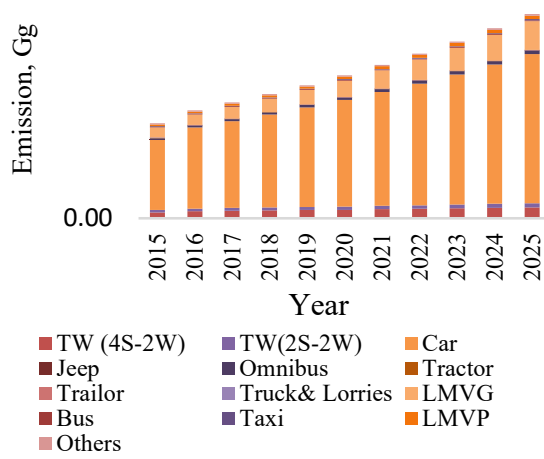

HC emission, Kolkata (2015-2025), Gg (g) 50.00

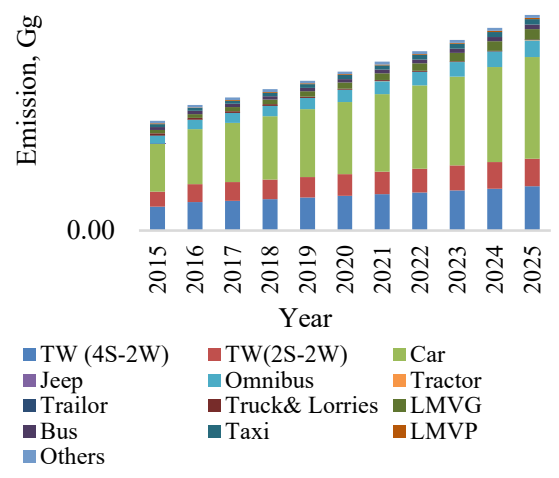

Fig. 3. Annual emission of Kolkata (2015-2025): A) $\mathrm{CO}_{2}$; B) $\mathrm{CO}$; (C) $\mathrm{NO}_{\mathrm{x}}$; (D) $\mathrm{CH}_{4}$; (E) $\mathrm{SO}_{2}$; (F) PM; (G) $\mathrm{HC}$.

The CO emission inventory of $126.15 \mathrm{Gg}$ during 2015 will be increased to $272.81 \mathrm{Gg}$ during 2025 by registering a rise of about $116 \%$, as can be seen in Fig. 3B. The cars will be the main contributor with $53 \%$ of the total emission of CO emission during 2025 followed by LMVG $(25 \%)$ and $4 \mathrm{~S}-2 \mathrm{~W}(8 \%)$. The projected increase of two-wheelers by $163 \%$ during $2015-$ 2025 will surely be a contributor to $\mathrm{CO}$ presence in the atmosphere as evident from the fact that they will be contributing to about $9 \%$ of the total $\mathrm{CO}$ emission of $272.81 \mathrm{Gg}$ during 2025.

The $52.66 \mathrm{Gg}$ of $\mathrm{NO}_{\mathrm{x}}$ emission during 2015 will be increased to $98.21 \mathrm{Gg}$ by 2025 due to vehicular road traffic as can be seen in Fig. 3C. The highest contribution of $42 \%$ of total $\mathrm{NO}_{\mathrm{x}}$ emission during 2025 will come from omnibuses, followed by $17 \%$ from LMVG, $15 \%$ from cars, and about $11 \%$ from the buses.

During 2015 the $\mathrm{CH}_{4}$ emission from road vehicles was $7.85 \mathrm{Gg}$ which will shoot up $16.9 \mathrm{Gg}$ during 2025 in Kolkata, the increase being $115 \%$. Four types of automobiles like 4S-2W $(5 \%), 2 \mathrm{~S}-2 \mathrm{~W}(2 \%)$, Cars $(73 \%)$, and LMVG (14\%) will be responsible for about $94 \%$ of 
CH4 emission during 2025 as can be seen in Fig. 3D. As it is evident from Fig. 3E, there will be $93.39 \mathrm{Gg} \mathrm{SO}_{2}$ emissions in Kolkata due to the vehicle population by 2025 , which is about $102 \%$ more than that of 2015 emissions. The major contributors to the pool of $\mathrm{SO}_{2}$ will be three types of vehicles like taxis, cars, and omnibuses, and out of these three, taxies alone responsible for $86 \%$ of the total $\mathrm{SO}_{2}$ emission inventory of the city by 2015 .

During 2025 there will be $8.60 \mathrm{Gg}$ of PM pollution in the city due to vehicle population, as shown in Fig. 3F, which will be about $110 \%$ higher than that of 2015 emissions. The main contributor to PM pollution in Kolkata during 2025 will be four types of automobiles viz. LMVG (31\%), Car (25\%), Omnibuses (23\%), and Taxies $(6.4 \%)$ constituting about $84.5 \%$ of the total during 2025. HC emission also includes other volatile organic compounds (VOCs) which may not be directly harmful to health at the concentration found in the ambient air. However, they support the formation of hazardous $\mathrm{NO}_{2}$ and $\mathrm{O}_{3}$ in the atmosphere. During 2015 the road vehicles contributed to about $19.6 \mathrm{Gg}$ of $\mathrm{HC}$ formation which is expected to increase to $38.55 \mathrm{Gg}$ during 2025 indicating a considerable sharp rise of about $97 \%$ as can be seen in Fig 3(G). The major contributor of $\mathrm{HC}$ will include emissions from 4S-2W (20\%), 2S-2W (13\%), cars (47\%) during 2025. Interestingly, two-wheelers (both 4S-2W and 2S$2 \mathrm{~W})$ together will be responsible for $33 \%$ of the total HC pollution coming out from the road vehicular transport sector in the city.

\subsection{GHG Emissions of Kolkata and 24 Other Indian Cities}

The IPCC, 2006 equation and category wise break up of total vehicles in the cities were used to calculate GHG emission for 25 leading million-plus Indian cities, including Kolkata. GHG emissions for 25 leading million-plus Indian cities for the year 2017 and category-wise vehicles of the cities responsible for the emissions can be seen in Table 2. Table 2 indicates that the total vehicle stock of 25 cities increased by $11 \%$ during $2015-2016,7 \%$ during 2016-2017, and $19 \%$ during 2015-2017. Table 2 also reveals that Delhi topped the list with mammoth 10.26 million vehicle stock during 2017, followed by cities like Bengaluru (6.83 million), Chennai (5.30 million). Ahmedabad (3.90 million), Mumbai (3.05 million), and Surat $(2.89$ million). It is interesting to note that the city of Kolkata is in 14th place out of 25 cities figured in Table 2.

In case of increase in vehicle stock of the cities, the highest rise during 2015-2017 took place for Rajkot and Vadodara with a remarkable $97 \%$ and $94 \%$ respectively. The vehicle stock for Bengaluru also grew by $24 \%$ during 2015-2017 followed by Kolkata (22\%), Aurangabad (21\%), Nagpur (20\%), Mumbai (19\%), and Meerut (18.62\%). Interesting to note that the vehicle population increased in Rajkot $(84 \%)$ and Vadodara $(82 \%)$ mostly during 2015-2016.

As the economy progressed, the population of the cities also increased which led pro-rata increase in total passenger travel demand with time. Accordingly, the transport emission load of Indian cities also increased with time. During 2017, all the 25 leading Indian cities emitted $220560 \mathrm{Gg}$ of $\mathrm{CO}_{2}$ (Table 2). Also, during 2017, across all the 25 cities, the leading $\mathrm{CO}_{2}$ emitting city was Delhi with $22 \%$ of total emission $(48317 \mathrm{Gg}$,), followed by Bengaluru (26 $285 \mathrm{Gg}, 12 \%$ ), Chennai (19 $418 \mathrm{Gg}, 9 \%$ ), Mumbai (15 989 Gg, $6 \%$ ), Ahmedabad (13 $104 \mathrm{Gg}, 6 \%$ ) and Kolkata (12 757Gg, $6 \%$ ). In terms of CO emission, Delhi also remained on the top during 2017 with $20 \%$ of the total emission $(630 \mathrm{Gg})$ followed by cities like Bengaluru (369 Gg, $12 \%$ ), Chennai (270 Gg, 8 \%), Ahmedabad (214 Gg, 7 \%), Mumbai (188 Gg, $7 \%$ ), and Kolkata (151 Gg, $5 \%$ ). During 2017, Bengaluru had the highest $\mathrm{NO}_{\mathrm{x}}$ emission $(121 \mathrm{Gg}, 14 \%$,) followed by Delhi $(110 \mathrm{Gg}, 12 \%)$, Chennai (89 Gg, $10 \%)$, Kolkata (59 Gg, $7 \%$ ), and Ahmedabad (57 Gg, $6 \%$ ). In terms of $\mathrm{CH}_{4}$ emissions, the top five cities were Delhi (65 Gg, $19 \%$ ), Bengaluru (45 Gg, $13 \%$ ), Chennai (38 Gg, $11 \%$ ), Ahmedabad (27 Gg, 8 \%), 
both Mumbai and Jaipur jointly stood seventh $(20 \mathrm{Gg}, 6 \%)$ while Kolkata (10 Gg, $2.9 \%)$ ranked 8th only. For $\mathrm{SO}_{2}$ emission, again Bengaluru topped the list with $108 \mathrm{Gg}(16 \%)$ followed by Delhi (102 Gg, $15 \%$ ) Chennai (97 Gg, $14 \%$ ), Mumbai (82 Gg, $12 \%$ ), and Kolkata in the 5 th position with $8 \%(52 \mathrm{Gg})$ of the total emission. It can also be seen from Table 2 that Kolkata was in the 5th rank, shared jointly with Mumbai, for PM (5 Gg, $6 \%$ ) emission while for $\mathrm{HC}$ emission, Kolkata ranked 8th with $24 \mathrm{Gg}$ (4\%) emission amongst the 25 cities.

TABLE 2. TOTAL GHG EMISSION IN 25 CitIES, 2017

\begin{tabular}{|c|c|c|c|c|c|c|c|c|c|c|}
\hline \multirow[t]{2}{*}{ Metro Cities } & \multicolumn{4}{|c|}{ Total no of vehicles, Mln } & \multicolumn{6}{|c|}{ Total Emission in 25 cities, 2017, $\mathbf{~ G g}$} \\
\hline & 2015 & 2016 & 2017 & $\mathrm{CO}_{2}$ & $\mathrm{CO}$ & $\mathrm{NO}_{\mathrm{x}}$ & $\mathbf{C H}_{4}$ & So & PM & HC \\
\hline Ahmedabad & 3.42 & 3.66 & 3.90 & 13104 & 214 & 57 & 27 & 25 & 6 & 51 \\
\hline Rajkot & 0.98 & 1.81 & 1.93 & 4932 & 89 & 23 & 8 & 10 & 2 & 25 \\
\hline Vadodara & 1.04 & 1.90 & 2.02 & 5756 & 99 & 25 & 8 & 14 & 3 & 26 \\
\hline Surat & 2.46 & 2.67 & 2.89 & 7400 & 135 & 29 & 10 & 7 & 3 & 37 \\
\hline Allahabad & 0.90 & 1.06 & 1.02 & 1330 & 35 & 10 & 3 & 4 & 1 & 13 \\
\hline Kanpur & 1.46 & 1.54 & 1.63 & 4585 & 65 & 18 & 5 & 4 & 1 & 22 \\
\hline Meerut & 0.53 & 0.57 & 0.62 & 1581 & 26 & 6 & 3 & 3 & 1 & 8 \\
\hline Varanasi & 0.77 & 0.78 & 0.91 & 2023 & 39 & 12 & 5 & 7 & 1 & 12 \\
\hline Lucknow & 1.71 & 1.82 & 1.98 & 5445 & 81 & 15 & 7 & 10 & 2 & 26 \\
\hline Bengaluru & 5.52 & 6.07 & 6.83 & 26285 & 369 & 121 & 45 & 109 & 10 & 92 \\
\hline Chennai. & 4.93 & 4.94 & 5.30 & 19418 & 270 & 89 & 38 & 97 & 7 & 71 \\
\hline Madurai & 0.95 & 0.96 & 1.04 & 2175 & 39 & 13 & 6 & 15 & 1 & 14 \\
\hline Delhi & 8.74 & 9.70 & 10.26 & 48317 & 630 & 110 & 65 & 103 & 13 & 139 \\
\hline Bhopal & 1.08 & 1.06 & 1.26 & 3743 & 56 & 22 & 6 & 12 & 2 & 17 \\
\hline Indore & 1.71 & 1.81 & 1.93 & 6353 & 93 & 46 & 10 & 13 & 3 & 27 \\
\hline Hyderabad & 2.37 & 2.37 & 2.71 & 8882 & 140 & 45 & 13 & 29 & 4 & 36 \\
\hline Jaipur & 2.25 & 2.43 & 2.58 & 9339 & 121 & 42 & 20 & 32 & 3 & 35 \\
\hline Jodhpur & 0.92 & 0.98 & 1.05 & 3663 & 50 & 21 & 7 & 13 & 2 & 14 \\
\hline Kota & 0.65 & 0.72 & 0.76 & 2074 & 31 & 10 & 4 & 5 & 1 & 10 \\
\hline Nagpur & 1.28 & 1.48 & 1.53 & 3411 & 62 & 16 & 7 & 6 & 1 & 20 \\
\hline Nashik & 0.62 & 0.68 & 0.71 & 2121 & 35 & 8 & 3 & 5 & 1 & 9 \\
\hline Aurangabad & 0.43 & 0.75 & 0.52 & 1158 & 25 & 8 & 4 & 2 & 1 & 7 \\
\hline Mumbai & 2.57 & 2.82 & 3.05 & 15989 & 196 & 39 & 20 & 82 & 4 & 41 \\
\hline Pune & 2.34 & 2.52 & 2.72 & 8720 & 133 & 33 & 16 & 17 & 3 & 36 \\
\hline Kolkata & 1.40 & 1.61 & 1.71 & 12757 & 151 & 59 & 10 & 52 & 5 & 24 \\
\hline Total & 51.03 & 56.71 & 60.86 & 220560 & 3185 & 879 & 351 & 676 & 81 & 810 \\
\hline
\end{tabular}

\subsection{GHG Emissions Per Unit Area of 25 Cities}

The city-wise emission per unit area for 25 cities for the year 2017 in respect of PM, CO, $\mathrm{CO}_{2}, \mathrm{NO}_{\mathrm{x}}, \mathrm{SO}_{2}, \mathrm{CH}_{4}$, and $\mathrm{HC}$ due to on-road vehicle stock is summarized in Table 3. It can be seen from Table 3 that though many cities outnumbered Kolkata in terms of their vehicle stock, regarding GHG gas emissions per unit city area, it remained in the top position. The $\mathrm{CO}_{2}$ emission contribution per unit area was highest in Kolkata with $62.23 \mathrm{Gg} \mathrm{km}^{-2}$ during 
2017, which was much higher than the 25 -city average of $24.52 \mathrm{Gg} \mathrm{km}^{-2}$. Other significant cities in terms of higher $\mathrm{CO}_{2}$ emission contribution per unit area were Delhi (61.94 $\mathrm{Gg} \mathrm{km}^{-2}$ ), Jodhpur (46.61 $\mathrm{Gg} \mathrm{km}^{-2}$ ), Chennai (45.58 $\mathrm{Gg} \mathrm{km}^{-2}$ ), Bengaluru (37.07 $\mathrm{Gg} \mathrm{km}^{-2}$ ), Mumbai (36.53 $\left.\mathrm{Gg} \mathrm{km}^{-2}\right)$, Rajkot $\left(29.01 \mathrm{Gg} \mathrm{km}^{-2}\right)$, and Ahmedabad $\left(28.24 \mathrm{Gg} \mathrm{km}^{-2}\right)$ as can be seen from Table 3 .

Kolkata was in the $2^{\text {nd }}$ position in terms of CO $\left(737 \mathrm{Mg} \mathrm{km}^{-2}\right)$ emission per unit area while the leading position was with Delhi $\left(808 \mathrm{Mg} \mathrm{km}^{-2}\right)$. Cities like Jodhpur $\left(634 \mathrm{Mg} \mathrm{km}^{-2}\right)$. Chennai $\left(633 \mathrm{Mg} \mathrm{km}^{-2}\right)$, Rajkot $\left(523 \mathrm{Mg} \mathrm{km}^{-2}\right)$, and Bengaluru $\left(521 \mathrm{Mg} \mathrm{km}^{-2}\right)$ had much higher $\mathrm{CO}$ emission per unit area than the 25 -city average of $372 \mathrm{Mg} \mathrm{km}^{-2}$. Kolkata topped the list of $\mathrm{NO}_{\mathrm{x}}$ emissions per unit area with $290 \mathrm{Mg} \mathrm{km}^{-2}$ during 2017. Cities like Jodhpur (266 Mg km${ }^{-2}$ ), Chennai $\left(210 \mathrm{Mg} \mathrm{km}^{-2}\right)$, and Bengaluru $\left(170 \mathrm{Mg} \mathrm{km}^{-2}\right.$ ) were also found to be well ahead of the 25-city per unit area average of $\mathrm{NO}_{\mathrm{x}}$ emission $\left(110 \mathrm{Mg} \mathrm{km}^{-2}\right)$. Kolkata held the $7^{\text {th }}$ position, amongst the 25 cities for $\mathrm{CH}_{4}$ emission per unit area $\left(51 \mathrm{Mg} \mathrm{km}^{-2}\right)$ after cities like Chennai $\left(89 \mathrm{Mg} \mathrm{km}^{-2}\right)$, Jodhpur $\left(86 \mathrm{Mg} \mathrm{km}^{-2}\right)$, Delhi $\left(84 \mathrm{Mg} \mathrm{km}^{-2}\right)$, Varanasi (65 $\mathrm{Mg} \mathrm{km}^{-2}$ ), Bengaluru (63 $\left.\mathrm{Mg} \mathrm{km}^{-2}\right)$, and Ahmedabad $\left(51 \mathrm{Mg} \mathrm{km}^{-2}\right)$. However, with $254 \mathrm{Mg} \mathrm{km}^{-2}$ of $\mathrm{SO}_{2}$ emission and $23 \mathrm{Mg} \mathrm{km}^{-2}$ of $\mathrm{PM}$ emission per unit area, Kolkata outpaced the other cities by a significant margin. In terms of $\mathrm{HC}$ emission, Kolkata ranked $8^{\text {th }}$ with $106 \mathrm{Mg} \mathrm{km}^{-2}$ where the leading cities were Delhi $\left(178 \mathrm{Mg} \mathrm{km}^{-2}\right)$, Jodhpur (173 $\mathrm{Mg} \mathrm{km}^{-2}$ ), Chennai (168 $\mathrm{Mg} \mathrm{km}^{-2}$ ), Allahabad (158 $\mathrm{Mg} \mathrm{km}^{-2}$ ), Rajkot (145 $\mathrm{Mg} \mathrm{km}^{-2}$ ), and Bengaluru (129 $\mathrm{Mg} \mathrm{km}^{-2}$ ).

All the 25 major million-plus cities are very important from the viewpoint of the Indian economy as they are the centre of many commercial and industrial establishment and providing livelihood and to a large chunk of the Indian population since the independence of the country. A recent report, Global Metro Monitor [8] indicates that higher $\mathrm{CO}_{2}$ emitting cities are also in the list of top ten wealthiest cities of India in terms of their Gross Domestic Product (GDP) contribution towards the national economy. The economic progress has also contributed towards total passenger travel demand and hence surge in the vehicle population. Fig. 4(A)-(C), drawn with the inputs from Table 3 present the increasing nature of emissions per unit area for the 25 cities during 2015-2017. The highest increase was recorded for Rajkot and Vadodara with $116 \%$ and $104 \%$ respectively during 2015-2017. Allahabad was the only city where $\mathrm{CO}_{2}$ emission per unit area gone down by $35 \%$ during 2015-2017. Interestingly, the $\mathrm{CO}_{2}$ emission per unit area for Delhi, with the largest vehicle stock, marginally increased by $15 \%$ (from $54 \mathrm{Gg} \mathrm{km}^{-2}$ to $62 \mathrm{Gg} \mathrm{km}^{-2}$ ) during 2015-2017. The other cities with a comparative higher increase of $\mathrm{CO}_{2}$ emission were Bhopal (26\%), Meerut (23\%), Nagpur (23\%), Bengaluru (22\%), Indore (22\%), Aurangabad (21\%), and Kolkata $(21 \%)$ during 2015-17. The average increase of CO emission per unit area across the 25 cities during 20152017 was $19 \%$. However, massive CO emission increased in Vadodara $(111 \%$, 146 to $308 \mathrm{Mg} \mathrm{km}^{-2}$ ) and Rajkot (106\%, 235 to $483 \mathrm{Mg} \mathrm{km}^{-2}$ ) during 2015-2017. CO emissions per unit area also grew in Nagpur (27\%) followed by Delhi $(24 \%)$, Bangalore (24\%), Bhopal (23\%), Indore (20\%), Jaipur (19\%), and Kolkata (19\%) during 2015-2016. The average increase in $\mathrm{NO}_{\mathrm{x}}$ emission per unit area across the 25 cities during 2015-2017 was $21 \%$. However, $\mathrm{NO}_{\mathrm{x}}$ emission significantly increased in cities like Bhopal (108\%), Vadodara (99\%), Rajkot (93\%), Indore (92\%), Delhi (50\%), Nagpur (29\%), Pune (28\%), Bengaluru (17\%) and Kolkata (15\%) during 2015-2016. The average increase in $\mathrm{CH}_{4}$ emission per unit area across the 25 cities during 2015-2016 was 24\%. Again, Vadodara and Rajkot led the cities in terms of increase of $\mathrm{CH}_{4}$ emission with $74 \%$ and $72 \%$ respectively during 2015 2016 followed by Delhi (36\%), Pune (31\%), Nagpur (25\%), Varanasi $(20 \%)$, Bhopal (19\%), Bengaluru (18\%), and Kolkata $(15 \%)$. The average $\mathrm{SO}_{2}$ emission per unit area across the 25 cities during 2015-2017 was $16 \%$. The city of Pune had the highest increase in 
$\mathrm{SO}_{2}$ emission per unit area during 2015-2016 with $137 \%$ followed by Rajkot (112\%), Delhi (99\%), Vadodara (94\%), Mumbai (77\%), Bengaluru (62\%), and Nagpur (60\%). Kolkata had a modest increase in $\mathrm{SO}_{2}$ emission of $8 \%$ per unit area during 2015-2017.

TABle 3. GHG EMISSION FOR 25 INDIAN CITIES PER Unit AREA DURING 2017

\begin{tabular}{|c|c|c|c|c|c|c|c|c|c|c|}
\hline \multirow{2}{*}{$\begin{array}{l}\text { Metro } \\
\text { Cities }\end{array}$} & \multirow{2}{*}{$\begin{array}{l}\text { Nr. of road } \\
\text { vehicles }\end{array}$} & \multirow[t]{2}{*}{$\%$ of total } & \multirow{2}{*}{$\begin{array}{l}\text { Area*, } \\
\text { km }^{2}\end{array}$} & \multirow{2}{*}{$\frac{\mathrm{CO}_{2}}{\mathrm{Gg} \mathrm{km}^{-2}}$} & \multirow{2}{*}{\multicolumn{2}{|c|}{$\begin{array}{l}\mathrm{CO} \quad \mathrm{NO}_{\mathrm{X}} \\
\mathrm{Mg} \mathrm{km}^{-2}\end{array}$}} & \multirow[t]{2}{*}{$\mathrm{CH}_{4}$} & \multirow[t]{2}{*}{$\mathrm{SO}_{2}$} & \multirow[t]{2}{*}{ PM } & \multirow[t]{2}{*}{$\mathrm{HC}$} \\
\hline & & & & & & & & & & \\
\hline Ahmedabad & 3904952 & 6.44 & 464 & 28.24 & 462 & 122 & 59 & 53 & 12 & 109 \\
\hline Rajkot & 1926305 & 3.18 & 170 & 29.01 & 523 & 137 & 45 & 60 & 14 & 145 \\
\hline Vadodara & 2021688 & 3.33 & 300 & 19.19 & 331 & 84 & 28 & 47 & 8 & 86 \\
\hline Surat & 2886950 & 4.76 & 326.5 & 22.66 & 415 & 88 & 32 & 23 & 9 & 114 \\
\hline Allahabad & 1022995 & 1.69 & 82 & 16.22 & 421 & 124 & 37 & 52 & 11 & 158 \\
\hline Kanpur & 1632682 & 2.69 & 403.7 & 11.36 & 162 & 45 & 12 & 10 & 3 & 55 \\
\hline Meerut & 623559 & 1.03 & 141.9 & 11.14 & 181 & 41 & 20 & 19 & 4 & 57 \\
\hline Varanasi & 906833 & 1.50 & 82.1 & 24.64 & 471 & 145 & 65 & 87 & 13 & 142 \\
\hline Lucknow & 1978345 & 3.26 & 349 & 15.60 & 233 & 44 & 21 & 27 & 4 & 75 \\
\hline Bengaluru & 6833080 & 11.27 & 709 & 37.07 & 521 & 170 & 63 & 153 & 15 & 129 \\
\hline Chennai & 5298883 & 8.74 & 426 & 45.58 & 633 & 210 & 89 & 228 & 17 & 168 \\
\hline Madhurai & 1037239 & 1.71 & 148 & 14.69 & 265 & 91 & 39 & 98 & 7 & 92 \\
\hline Delhi & 10260052 & 16.92 & 780 & 61.94 & 808 & 141 & 84 & 133 & 17 & 178 \\
\hline Bhopal & 1255784 & 2.07 & 285.9 & 13.09 & 197 & 78 & 22 & 41 & 6 & 59 \\
\hline Indore & 1934588 & 3.19 & 530 & 11.99 & 176 & 87 & 19 & 24 & 6 & 50 \\
\hline Hyderabad & 2714510 & 4.48 & 367 & 24.20 & 381 & 124 & 35 & 79 & 11 & 99 \\
\hline Jaipur & 2583107 & 4.26 & 484.6 & 19.27 & 250 & 87 & 42 & 66 & 7 & 72 \\
\hline Jodhpur & 1051813 & 1.73 & 78.6 & 46.61 & 634 & 266 & 86 & 166 & 20 & 173 \\
\hline Kota & 763690 & 1.26 & 527 & 3.94 & 59 & 18 & 7 & 10 & 1 & 19 \\
\hline Nagpur & 1526777 & 2.52 & 227.4 & 15.00 & 274 & 72 & 32 & 28 & 6 & 89 \\
\hline Nashik & 707918 & 1.17 & 264.2 & 8.03 & 133 & 32 & 11 & 17 & 3 & 33 \\
\hline Aurangabad & 515481 & 0.85 & 139 & 8.33 & 183 & 58 & 26 & 15 & 6 & 47 \\
\hline Mumbai & 3052901 & 5.03 & 437.71 & 36.53 & 447 & 89 & 46 & 187 & 10 & 93 \\
\hline Pune & 2717322 & 4.48 & 331.3 & 26.32 & 400 & 99 & 47 & 52 & 9 & 109 \\
\hline Kolkata & 1709192 & 2.82 & 205 & 62.23 & 737 & 290 & 51 & 254 & 23 & 119 \\
\hline Total & 60866646 & 100 & $330 *$ & $24.52^{*}$ & $372 *$ & $110^{*}$ & $41^{*}$ & $77^{*}$ & $10^{*}$ & $99 *$ \\
\hline
\end{tabular}

Source: Author's calculations using [38] equation. * 25 city average

** City geographical area

Though the average PM emission per unit area across the 25 cities during 2015-2017 was $21 \%$, two cities like Vadodara and Rajkot registered a much higher rise of $112 \%$ and $103 \%$ respectively during the same period. Bhopal (48\%), Indore (45\%), Delhi (42\%), Nagpur ( $30 \%)$, and Bengaluru (23\%) were the other cities with a reckonable rise in PM emission during 2015-2017 as can be seen from the Fig. 4(A)-(C) and also Table 3. In comparison, Kolkata had a modest rise of PM (15\%) during the same period. 


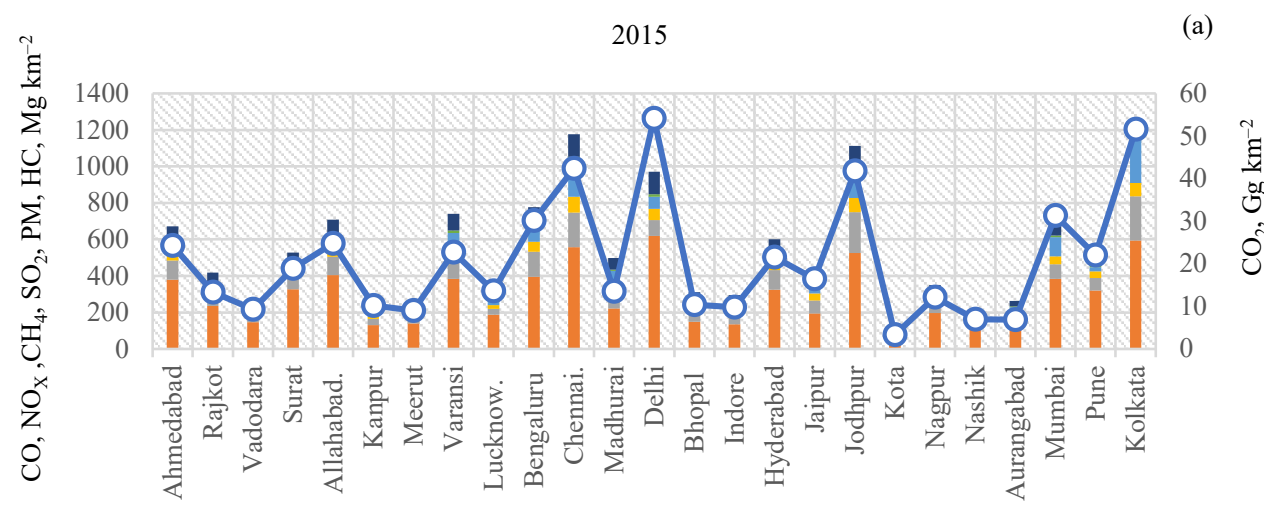

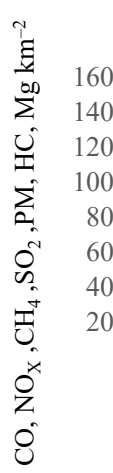

2016

(b)

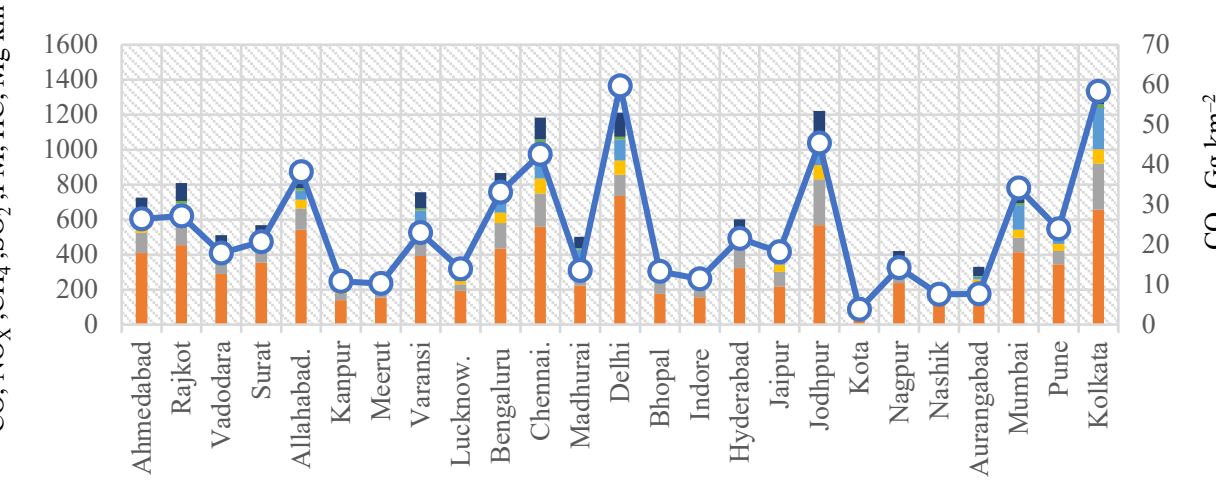

$\begin{array}{lllll}\mathrm{CO} & \mathrm{NOX} & \mathrm{CH} 4 & \mathrm{SO} 2 & \mathrm{HC}\end{array}$

2017

(c)

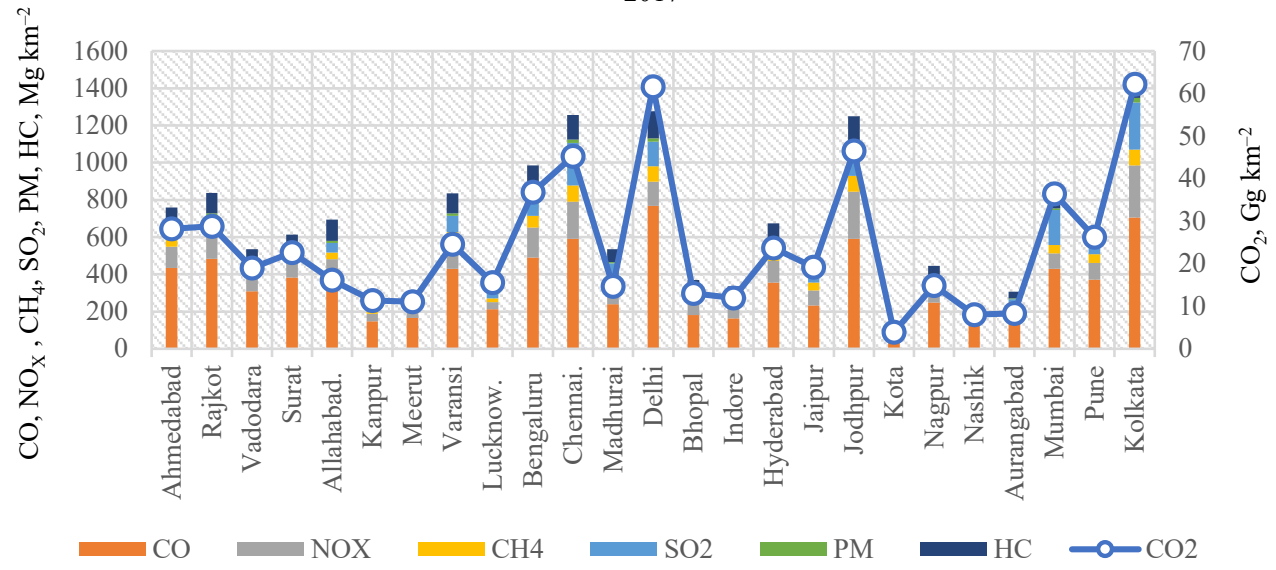

Fig. 4. GHG emission per unit area across 25 cities: A) 2015; B) 2016; C) 2017. 
The HC emission per unit area across the 25 cities during 2015-2017 was $20 \%$. Again, the two cities of Rajkot and Vadodara topped the list of increase in HC emission level during 2015-2017 with $94 \%$ and 92\% respectively. Three cities like Bengaluru, Bhopal, and Kolkata came next with a $22 \%$ rise of HC in each of the cities during 2015-2017.

\subsection{Emission from Different Vehicle Types of Metropolitan Cities}

Emission contributions from different types of vehicles during 2017 for the top five metropolitan cities, i.e., Bangalore, Mumbai, Delhi, Chennai, and Kolkata were calculated using the IPCC equation and summarized in Table 4. It can be observed that in Bangalore, out of $26143 \mathrm{Gg}$ of $\mathrm{CO}_{2}$ emissions during 2017, the highest emission came from cars $(71.18 \%, 18609 \mathrm{Gg})$, followed by taxis $(7.06 \%, 1845 \mathrm{Gg})$, truck and lorries $(5.06 \%$, $1323 \mathrm{Gg})$ and buses plus omnibuses combination $(7.61 \%, 1991 \mathrm{Gg})$. Similarly, the highest contributor of $\mathrm{CO}$ in Bangalore was cars $(47.4 \%, 164.8 \mathrm{Gg})$ followed by two-wheelers (18.86 \%, $65.6 \mathrm{Gg})$, LMVG (11.39\%, $39.6 \mathrm{Gg})$, and LMVP (10.99\%, $38.2 \mathrm{Gg})$. The highest contributor for $\mathrm{NO}_{\mathrm{x}}$ were buses plus omnibuses combination $(40.58 \%, 46.4 \mathrm{Gg})$ followed by trucks and lorries $(14.16 \%, 16.2 \mathrm{Gg})$. For $\mathrm{CH}_{4}$, the highest contributor was cars $(61.01 \%$, $14.2 \mathrm{Gg}$ ) while for $\mathrm{SO}_{2}, \mathrm{PM}$ and $\mathrm{HC}$, the highest contributors were taxis $(83.91 \%, 91 \mathrm{Gg})$, cars $(22.8 \%, 2.5 \mathrm{Gg})$, two-wheelers $(58.09 \%, 42.3 \mathrm{Gg})$ respectively. Emission analysis of Mumbai, based on the vehicle types, reveals that cars and taxis (car: $80 \%$, taxis $10 \%$ ) together contributed to about $90 \%$ of $\mathrm{CO}_{2}$ emission of $15956 \mathrm{Gg}$ while cars and two-wheelers (car: $61 \%$, two-wheelers $13 \%$ ) together contributed about $74 \%$ of CO emission of $187.8 \mathrm{Gg}$ during 2017. Similarly, two-wheelers were the primary source of HC emission ( $16 \mathrm{Gg}$; $48 \%$ ), $\mathrm{CH}_{4}(2.0 \mathrm{Gg} ; 15 \%)$, and PM $(0.6 \mathrm{Gg} ; 12 \%)$ in Mumbai. Cars were a major source for $\mathrm{CH}_{4}$ (9.8 Gg, $72 \%$ ), HC (14.4 Gg, $43 \%$ ), PM (1.7 Gg, $36 \%$ ), and $\mathrm{NO}_{\mathrm{x}}(11.5 \mathrm{Gg}, 32 \%)$ emission while taxis accounted for very high $\mathrm{SO}_{2}(76.9 \mathrm{Gg}, 94 \%)$ emission in the city of Mumbai. In Kolkata, cars $(9451 \mathrm{Gg}, 74 \%)$ and omnibuses $(1041 \mathrm{Gg}, 8 \%)$ contributed the majority (82\%) of total $\mathrm{CO}_{2}$ emissions $(12757 \mathrm{Gg})$ while Car $(83.7 \mathrm{Gg}, 58 \%$ ) and LMVG $(27.4 \mathrm{Gg}$, $19 \%$ ) contributed for $77 \%$ of total CO emission in the city during 2017. Taxis and cars were a major source of $\mathrm{SO}_{2}$ emission $\left(43.5 \mathrm{Gg}, 83 \%\right.$ ) and $\mathrm{CH}_{4}$ emission $(7.2 \mathrm{Gg}, 75 \%$ ). Cars (1.3 Gg, $26 \%$ ), Omnibuses (1.1 Gg, $23 \%)$, and LMVG (1.1 Gg, $22 \%)$, together contributed about $71 \%$ of total PM in the city air. Cars $(10.6 \mathrm{Gg}, 48 \%)$ and two-wheelers $(6.7 \mathrm{Gg}, 31 \%)$ jointly contributed to about $79 \%$ of total $\mathrm{HC}$ in the city. In the case of Delhi, a city with a large vehicle stock, $90 \%$ of total $\mathrm{CO}_{2}(43106 \mathrm{Gg})$ was emitted by its cars while car $(381.7$ $\mathrm{Gg}, 64 \%$ ) and LMVG (93.1 Gg, $16 \%$ ) together contributed $80 \%$ of total CO emission during 2017. Cars $\left(38.6,38 \%\right.$ ) and LMVG $(23.4 \mathrm{Gg}, 23 \%)$ jointly contributed to $61 \%$ of total $\mathrm{NO}_{\mathrm{x}}$ emitted in the city. The single most significant $\mathrm{SO}_{2}$ contributor was the taxies $(89.4 \mathrm{Gg}, 86 \%)$ plying in Delhi city while cars $(5.8 \mathrm{Gg}, 42 \%)$ and LMVG (3.7 Gg, $26 \%$ ) were the leading contributors of total PM. Cars $(48.2 \mathrm{Gg}, 43 \%)$ and two-wheelers combination $(59.0 \mathrm{Gg}$, $52 \%$ ) was responsible for $95 \%$ of $\mathrm{HC}$ emission of Delhi. For Chennai city, cars were the leading contributor $\left(12959 \mathrm{Gg}, 67 \%\right.$ ) for total $\mathrm{CO}_{2}$ emission $(19266 \mathrm{Gg})$ during 2017 while cars $(114.8 \mathrm{Gg}, 45 \%)$ and two-wheelers $(52.5 \mathrm{Gg}, 21 \%)$ combination was responsible for $66 \%$ of $\mathrm{CO}$ emission in the city. Buses $(21.3 \mathrm{Gg}, 25 \%)$, Truck and lorries $(16.5,20 \%)$, and cars $(11.6 \mathrm{Gg}, 14 \%)$ together emitted the bulk $(59 \%)$ of total $\mathrm{NO}_{\mathrm{x}}$ in the city. Cars $(9.9 \mathrm{Gg}$, $59 \%$ ) and two-wheelers $(4.3 \mathrm{Gg}, 26 \%)$ jointly emitted $85 \%$ of total $\mathrm{CH}_{4}$ while taxis of Chennai solely contributed $84 \%(81.5 \mathrm{Gg})$ of $\mathrm{SO}_{2}$ emission.

Comparison across five cities reveals that cars were responsible for $49 \%$ of $\mathrm{CO}_{2}$ emission for Chennai followed by $40 \%$ for Bengaluru, $35 \%$ for Kolkata, $24 \%$ for Mumbai, and only $12 \%$ for Delhi during 2017. Also, cars were responsible for $64 \%$ of the total CO of Delhi, followed by $61 \%$ for Mumbai, and $55 \%$ for Kolkata. $\mathrm{NO}_{\mathrm{x}}$ emissions of Kolkata (41\%) and 
Bengaluru (21\%) were due to omnibuses while for Delhi (38\%) and Mumbai (32\%) it was cars. $\mathrm{SO}_{2}$ emission was hugely dependent on taxis as revealed from Table 4 that they were contributing $94 \%$ of the total for Mumbai followed by Delhi (86\%), Chennai (84\%), Bengaluru (84\%), and Kolkata (83\%). Cars were responsible for $\mathrm{CH}_{4}$ and $\mathrm{PM}$ emission for Bengaluru $\left(\mathrm{CH}_{4}, 61 \%\right.$; PM, $\left.23 \%\right)$, Mumbai $\left(\mathrm{CH}_{4}, 72 \%\right.$; PM, $\left.36 \%\right)$, Kolkata $\left(\mathrm{CH}_{4}, 75 \%\right.$; PM, $27 \%)$, Delhi $\left(\mathrm{CH}_{4}, 74 \%\right.$; PM, $\left.42 \%\right)$ and Chennai $\left(\mathrm{CH}_{4}, 59 \%\right.$; PM, $\left.22 \%\right)$. Twowheelers contributed $60 \%$ of total HC for Chennai, $58 \%$ for Bengaluru, $52 \%$ for Delhi, $48 \%$ for Mumbai, and $36 \%$ for Kolkata.

TABLE 4. EMISSION FROM DifFERENT VeHICLE TyPeS IN FiVe Metropolitan CiTIES OF INDIA (GG), 2017

\begin{tabular}{llllllllllllll}
\hline BL & TL & LG & BU & TA & LP & TW & CA & JP & OB & TT & TL & OT & Total \\
\hline $\mathbf{C O}_{2}$ & 1323 & 468 & 930 & 1845 & 314 & 793 & 18609 & 108 & 1061 & 158 & 121 & 412 & 26143 \\
\hline $\mathbf{C O}$ & 9.3 & 39.6 & 6.5 & 8.0 & 38.2 & 65.6 & 164.8 & 1.0 & 7.4 & 1.6 & 1.2 & 4.6 & 347.6 \\
\hline NO$_{\mathbf{x}}$ & 16.2 & 9.9 & 21.7 & 4.4 & 9.6 & 5.7 & 16.7 & 0.1 & 24.7 & 0.4 & 0.3 & 4.7 & 114.3 \\
\hline $\mathbf{C H}_{4}$ & 0.2 & 1.4 & 0.2 & 0.1 & 1.4 & 5.4 & 14.2 & 0.1 & 0.2 & 0.03 & 0.0 & 0.1 & 23.2 \\
\hline $\mathbf{S O}_{2}$ & 3.7 & 0.2 & 2.6 & 91.2 & 0.2 & 0.4 & 4.4 & 0.0 & 3.0 & 0.4 & 0.3 & 2.3 & 108.7 \\
\hline $\mathbf{P M}$ & 0.7 & 1.6 & 1.0 & 0.6 & 1.5 & 1.5 & 2.5 & 0.0 & 1.2 & 0.06 & 0.1 & 0.3 & 11.0 \\
\hline $\mathbf{H C}$ & 2.2 & 1.1 & 1.6 & 1.2 & 1.1 & 42.3 & 20.8 & 0.1 & 1.8 & 0.04 & 0.0 & 0.7 & 72.9 \\
\hline
\end{tabular}

MU

\begin{tabular}{llllllllllllll}
\hline $\mathbf{C O}_{2}$ & 54.3 & 177.9 & 295.3 & 1555 & 212 & 299.1 & 12838 & 415.5 & 80.2 & 2.07 & 1.1 & 25.32 & 15956 \\
\hline $\mathbf{C O}$ & 0.4 & 15.1 & 2.1 & 6.7 & 20.6 & 24.7 & 113.7 & 3.7 & 0.6 & 0.0 & 0.0 & 0.3 & 187.8 \\
\hline $\mathbf{N O}_{\mathbf{x}}$ & 0.7 & 3.8 & 6.9 & 3.7 & 5.2 & 2.1 & 11.5 & 0.4 & 1.9 & 0.0 & 0.0 & 0.3 & 36.4 \\
\hline $\mathbf{C H}_{4}$ & 0.0 & 0.5 & 0.1 & 0.1 & 0.7 & 2.0 & 9.8 & 0.3 & 0.0 & 0.0 & 0.0 & 0.0 & 13.5 \\
\hline $\mathbf{S O}_{2}$ & 0.2 & 0.1 & 0.8 & 76.9 & 0.1 & 0.2 & 3.0 & 0.1 & 0.2 & 0.0 & 0.0 & 0.1 & 81.7 \\
\hline $\mathbf{P M}$ & 0.0 & 0.6 & 0.3 & 0.5 & 0.8 & 0.6 & 1.7 & 0.1 & 0.1 & 0.0 & 0.0 & 0.0 & 4.7 \\
\hline $\mathbf{H C}$ & 0.1 & 0.4 & 0.5 & 1.0 & 0.6 & 16.0 & 14.4 & 0.5 & 0.1 & 0.0 & 0.0 & 0.0 & 33.5 \\
\hline
\end{tabular}

$\mathbf{K L}$

\begin{tabular}{llllllllllllll}
\hline $\mathbf{C O}_{2}$ & 185.9 & 323.5 & 337.3 & 879.6 & 54.8 & 126.7 & 9451 & 0.0 & 1041 & 55.4 & 2.42 & 299.7 & 12757 \\
\hline $\mathbf{C O}$ & 1.3 & 27.4 & 2.4 & 3.8 & 4.6 & 17.0 & 83.7 & 0.0 & 7.3 & 0.6 & 0.0 & 3.4 & 151.4 \\
\hline $\mathbf{N O}_{\mathbf{x}}$ & 2.3 & 6.9 & 7.9 & 2.1 & 1.2 & 2.3 & 8.5 & 0.0 & 24.2 & 0.1 & 0.0 & 3.4 & 58.8 \\
\hline $\mathbf{C H}_{4}$ & 0.0 & 1.0 & 0.1 & 0.0 & 0.2 & 0.9 & 7.2 & 0.0 & 0.18 & 0.0 & 0.0 & 0.1 & 9.6 \\
\hline $\mathbf{S O}_{2}$ & 0.5 & 0.2 & 1.0 & 43.5 & 0.0 & 0.1 & 2.2 & 0.0 & 2.9 & 0.2 & 0.0 & 1.7 & 52.1 \\
\hline $\mathbf{P M}$ & 0.1 & 1.1 & 0.4 & 0.3 & 0.2 & 0.1 & 1.3 & 0.0 & 1.1 & 0.0 & 0.0 & 0.2 & 4.8 \\
\hline $\mathbf{H C}$ & 0.3 & 0.8 & 0.6 & 0.6 & 0.1 & 8.7 & 10.6 & 0.0 & 1.8 & 0.0 & 0.0 & 0.5 & 3.80
\end{tabular}

DL

\begin{tabular}{llllllllllllll}
\hline $\mathrm{CO}_{2}$ & 39.6 & 1101 & 900.1 & 1807 & 0.0 & 1105 & 43106 & 0.0 & 0.1 & 2.3 & 0.0 & 22.6 & 48083 \\
\hline $\mathrm{CO}$ & 0.3 & 93.1 & 6.3 & 7.8 & 19.2 & 91.4 & 381.7 & 0.0 & 0.0 & 0.0 & 0.0 & 0.3 & 600.0 \\
\hline $\mathrm{NO}_{\mathbf{x}}$ & 0.5 & 23.4 & 21 & 4.3 & 4.8 & 7.9 & 38.6 & 0.0 & 0.0 & 0.01 & 0.0 & 0.3 & 100.7 \\
\hline $\mathrm{CH}_{4}$ & 0.0 & 3.4 & 0.2 & 0.1 & 0.7 & 7.5 & 32.8 & 0.0 & 0.0 & 0.0 & 0.0 & 0.0 & 44.5 \\
\hline
\end{tabular}




\begin{tabular}{llllllllllllll}
\hline $\mathbf{S O}_{2}$ & 0.1 & 0.5 & 2.5 & 89.4 & 0.1 & 0.5 & 10.2 & 0.0 & 0.0 & 0.0 & 0.0 & 0.1 & 103.5 \\
\hline $\mathbf{P M}$ & 0.0 & 3.7 & 1.0 & 0.6 & 0.8 & 2.1 & 5.8 & 0.0 & 0.0 & 0.0 & 0.0 & 0.0 & 13.9 \\
\hline $\mathbf{H C}$ & 0.1 & 2.6 & 1.5 & 1.1 & 0.5 & 59.0 & 48.2 & 0.0 & 0.0 & 0.0 & 0.0 & 0.0 & 113.0 \\
\hline
\end{tabular}

CN

\begin{tabular}{llllllllllllll}
\hline $\mathbf{C O}_{2}$ & 1346 & 349.3 & 913 & 1649 & 76.3 & 635.1 & 12959 & 179 & 190.5 & 29.8 & 127 & 813 & 19266 \\
\hline $\mathbf{C O}$ & 9.4 & 29.5 & 6.4 & 7.1 & 19 & 52.5 & 114.8 & 1.6 & 1.3 & 0.3 & 1.3 & 9.1 & 252.3 \\
\hline $\mathbf{N O}_{\mathbf{x}}$ & 16.5 & 7.4 & 21.3 & 4.0 & 4.8 & 4.5 & 11.6 & 0.2 & 4.4 & 0.1 & 0.3 & 9.2 & 84.2 \\
\hline $\mathbf{C H}_{4}$ & 0.2 & 1.0 & 0.2 & 0.1 & 0.7 & 4.3 & 9.9 & 0.1 & 0.0 & 0.0 & 0.0 & 0.3 & 16.8 \\
\hline $\mathbf{S O}_{2}$ & 3.7 & 0.2 & 2.5 & 81.5 & 0.1 & 0.3 & 3.1 & 0.0 & 0.5 & 0.1 & 0.4 & 4.6 & 97.0 \\
\hline $\mathbf{P M}$ & 0.7 & 1.2 & 1.0 & 0.6 & 0.8 & 1.2 & 1.7 & 0.0 & 0.2 & 0.0 & 0.1 & 0.6 & 8.0 \\
\hline $\mathbf{H C}$ & 2.3 & 0.8 & 1.5 & 1.0 & 0.5 & 34 & 14.5 & 0.2 & 0.3 & 0.0 & 0.0 & 1.3 & 56.4 \\
\hline
\end{tabular}

Abbreviations: TL: Truck, Lorries; LG: LMVG; BU: Buses; TA: Taxis; LP: LMVP; TW: Two-wheelers; CA: Car; JP: Jeep; OB: Omnibuses; TT: Tractor TL: Trailer; OT: Others; BL: Bangalore; MU: Mumbai; KL: Kolkata; DL: Delhi; CN: Chennai.

\section{CONCLusion}

City-wise emission inventory, exclusively for the road transport sector, is of utmost importance for India as the country depends heavily on the road network for freight and passenger traffic movements. Benefits from city-wise emission inventory would be in terms of timely policy prescription mitigation of vehicular emission and reduction of $\mathrm{GHG}$ emissions. The road transport led emission inventory for a representative Indian city, i.e., Kolkata for the period 2015-2025 has been assessed. The road transport led emission inventory for 25 million-plus population Indian cities including Kolkata for the year 20152017 has been assessed and their GHG emissions per unit area have been compared. It is estimated that there would be about 2.79 million vehicle stock in the city of Kolkata during 2025 resulting in increased emission of pollutants in the city by 2025 . By 2025 the vehicular emission of Kolkata will reach to massive $21668.24 \mathrm{Gg}$ of $\mathrm{CO}_{2}, 272.81 \mathrm{Gg}$ of $\mathrm{CO}, 98.21 \mathrm{Gg}$ of $\mathrm{NO}_{\mathrm{x}}, 16.9 \mathrm{Gg}_{\mathrm{C}} \mathrm{CH}_{4}, 93.39 \mathrm{Gg}$ of $\mathrm{SO}_{2}, 8.6 \mathrm{Gg}$ of PM, and $38.55 \mathrm{Gg}$ of $\mathrm{HC}$.

The rapid urbanization of the cities led to an increase in total passenger travel demand with time. Accordingly, the vehicle stock of the 25 million-plus leading cities increased by $19 \%$ during 2015-2017. In terms of vehicle stock, Delhi topped the list with mammoth 10.26 million vehicles during 2017, followed by cities like Bengaluru (6.83 million), Chennai (5.30 million). Ahmedabad (3.90 million), Mumbai (3.05 million), and Surat (2.89 million). The city Rajkot and Vadodara had the highest rise of vehicle stock with $97 \%$ and $94 \%$ respectively followed by the south Indian city Bengaluru (24\%), Kolkata (22\%), Aurangabad (21\%), Nagpur (20\%), Mumbai (19\%) and Meerut (18.62\%). With the increase in vehicle stock, the transport emission load on the Indian cities also increased [49]. During 2017, all the 25 leading Indian cities together emitted $220560 \mathrm{Gg}$ of $\mathrm{CO}_{2}$. Delhi had the highest vehicular emission contribution during 2017 with $22 \%$ of the total $\mathrm{CO}_{2}$ emission followed by cities like Bengaluru (26 $285 \mathrm{Gg}, 12 \%$ ), Chennai (19 $418 \mathrm{Gg}, 9 \%$ ), Mumbai (15 $989 \mathrm{Gg}, 7 \%$ ), Ahmedabad (13 $104 \mathrm{Gg}, 6 \%$ ) and Kolkata (12 $757 \mathrm{Gg}, 6 \%$ ). In terms of $\mathrm{CO}, \mathrm{NO}_{\mathrm{x}}, \mathrm{CH}_{4}, \mathrm{SO}_{2}, \mathrm{PM}$, and $\mathrm{HC}$ emission Kolkata ranked sixth (151 Gg, $5 \%$ ), fourth (59 $\mathrm{Gg}, 7 \%$ ), eighth (10 Gg, $2.9 \%$ ), fifth (52 Gg, $8 \%$ ), fifth (5 Gg, $6 \%$ ) and eighth $(24 \mathrm{Gg}, 4 \%)$ respectively out of the 25 cities total emission $(3185 \mathrm{Gg})$. 
In terms of GHG emissions per square kilometre of the city area, Kolkata topped the list amongst 25 million-plus cities. The $\mathrm{CO}_{2}$ emission contribution per unit area was highest in Kolkata with $62 \mathrm{Gg} \mathrm{km}^{-2}$ during 2017, which was significantly higher than the 25-city average of $24 \mathrm{Gg} \mathrm{km}^{-2}$. The city also outpaced the other 24 cities by a significant margin with $254 \mathrm{Mg} \mathrm{km}^{-2} \mathrm{SO}_{2}$ emission, $23 \mathrm{Mg} \mathrm{km}^{-2} \mathrm{PM}$ emission, and $290 \mathrm{Mg} \mathrm{km}^{-2}$ for $\mathrm{NO}_{\mathrm{x}}$ during 2017. Kolkata occupied the second position in terms of $\mathrm{CO}$ emission per unit area $\left(737 \mathrm{Mg} \mathrm{km}^{-2}\right)$, the seventh position for $\mathrm{CH}_{4}$ emission $\left(51 \mathrm{Mg} \mathrm{km}^{-2}\right)$, and the eighth position for $\mathrm{HC}$ emission per unit area $\left(106 \mathrm{Mg} \mathrm{km}^{-2}\right)$ amongst the 25 cities considered in this study.

Emission analysis based on pollution contribution of different types of road transport vehicles for five metropolitan cities, i.e., Bangalore, Mumbai, Delhi, Chennai, and Kolkata reveal that cars were primarily responsible for $\mathrm{CO}_{2}, \mathrm{CO}, \mathrm{NO}_{\mathrm{x}}, \mathrm{CH}_{4}$, and $\mathrm{PM}$ emission in these five cities during 2017. At the same time, taxies were responsible for $\mathrm{SO}_{2}$ emission and twowheelers for $\mathrm{HC}$ emission. For Kolkata, cars were responsible for $35 \%$ for $\mathrm{CO}_{2}, 55 \%$ of CO, $75 \%$ of $\mathrm{CH}_{4}, 27 \%$ of $\mathrm{PM}$, omnibuses for $41 \%$ for $\mathrm{NO}_{x}$ emission, taxis for $83 \%$ of $\mathrm{SO}_{2}$, and two-wheelers $36 \%$ for $\mathrm{HC}$ emissions during 2017. The identification of vehicle categories responsible for major emissions in cities will be handy for the city policymakers to come up with appropriate policy options to curb emissions from the road transport sector.

Alarmed by the huge vehicular pollution in cities, the central government has taken several initiatives like increasing the $\mathrm{CNG}$ network to cover more cities, expansion of metro rail networks, and introducing electric vehicles in the cities. However, most remarkable was the recent decision to leapfrog from BS-IV fuel to BS-VI fuel without shifting to BS-V fuel (Indian equivalent to Euro-IV to Euro-VI) and hence directed only BS-VI compliant vehicles should be sold in the country from April 1st, 2020. No doubt, this drastic step was the need of the hour for Indian cities, and it is likely to improve the city air quality. However, the existing BS-IV compliant vehicles have been allowed to remain operational for their entire duration of registration. Both BS-VI fuel and BS-VI compliant vehicles will surely bring down vehicular emission resulting in better air quality in cities. This study, therefore, is very timely and vital from the point of view that it would provide a benchmark to the policymakers and researchers for comparing the emission improvement in the 25 representative cities of India resulting from new initiatives to clean city air in the years to come. Our study has a few limitations as well. The non-availability of updated (type-wise) vehicle utilization rates and emission factors for diesel and gasoline vehicles separately under different engine standards like BS-I to BS-V impaired the total emission estimation. Further, the non-availability of data regarding the numbers of the new vehicles added up in the city stock with technologies per year and year-wise phasing out of vehicles with old technologies made it difficult to bring out the benefits of technological improvements in emission reduction at different point of time.

\section{ACKNOWLEDGEMENT}

This study was supported by the Graduate School Thesis Grant, Chulalongkorn University, Bangkok, Thailand.

\section{REFERENCES}

[1] Khare A. Planet earth and automobiles, with special reference to the Indian Vehicle Industry. Technovation 1998:18(5):353-359. https://doi.org/10.1016/S0166-4972(98)00017-0

[2] Pal R., et al. 18-Year Ambient $\mathrm{PM}_{2.5}$ Exposure and Night Light Trends in Indian Cities: Vulnerability Assessment. Aerosol and Air Quality Research 2018:18:2332-2342. https://doi.org/10.4209/aaqr.2017.10.0425 
[3] WHO. Global Urban Ambient Air Pollution Database (update 2016) [Online]. [Accessed 02.06 2020]. Available: https://www.who.int/airpollution/data/cities-2016/en/

[4] Central Pollution Control Board. National Ambient Air Quality Status 2009. Delhi: Ministry of Environment \& Forests, 2009.

[5] World Bank. India transportation, 2011 [Online]. [Accessed 12.05.2020]. Available: https://www.worldbank.org/en/news/feature/2011/09/23/india-transportation

[6] Mondal R., et al. Ground level concentration of nitrogen oxides $\left(\mathrm{NO}_{\mathrm{x}}\right)$ at some traffic intersection points in Calcutta. Atmospheric Environment 2000:34(4):629-633. https://doi.org/10.1016/S1352-2310(99)00216-2

[7] Gurjar B. R., Nagpure A. S. Indian megacities as localities of environmental vulnerability from air quality perspective. Journal of Smart Cities 2015:1(1):15-30. https://doi.org/10.18063/JSC.2015.01.003

[8] Bouchet M., et al. Global Metro Monitor Brookings 2018. Washington: MPP, 2018.

[9] Ramanathan R. Link between population and number of vehicles. Evidence from Indian cities. Cities 2000:17(4):263269. https://doi.org/10.1016/S0264-2751(00)00022-6

[10] Das A., Parikh J. Transport scenarios in two metropolitan cities in India: Delhi and Mumbai. Energy Conversion and Management 2004:45(15-16):2603-2625. https://doi.org/10.1016/j.enconman.2003.08.019

[11] Badami M. G. Transport and urban air pollution in India. Environmental Management 2005:36(2):195204. https://doi.org/10.1007/s00267-004-0106-x

[12] Mukherjee A., Mukherjee G. Occupational exposure of the traffic personnel of Calcutta to lead and carbon monoxide. Pollution and Research 1998:17(4):359-362.

[13] Kazimuddin A., Banerjee L. Fighting for Air. Down to Earth. 2000.

[14] Ramachandra T. V., Shwetmala. Emissions from India's transport sector: State wise synthesis. Atmospheric Environment 2009:43(34):5510-5517. https://doi.org/10.1016/j.atmosenv.2009.07.015

[15] Gurjar B. R., et al. Emission estimates and trends (1990-2000) for mega-city Delhi and implications. Atmospheric Environment 2004:38(33):5663-5681. https://doi.org/10.1016/j.atmosenv.2004.05.057

[16] Nagpure A. S., Gurjar B. R. Development and evaluation of vehicular air pollution inventory model. Atmospheric Environment 2012:59:160-169. https://doi.org/10.1016/j.atmosenv.2012.04.044

[17] Rajasekhar R. V. J., et al. A study on automobile emission patterns in Madurai city. Pollution Research 2005:24(4):767-768.

[18] Goyal P., Mishra D., Kumar A. Vehicular emission inventory of criteria pollutants in Delhi. Springer Plus 2014:2:216. https://doi.org/10.1186/2193-1801-2-216

[19] Goel R., et al. Assessment of motor vehicle use characteristics in three Indian cities. Transport Research Part D: Transport and Environment 2015:44:254-265. https://doi.org/10.1016/j.trd.2015.05.006

[20] Sindhwani R., Goyal P. Assessment of traffic-generated gaseous and particulate matter emissions and trends over Delhi (2000-2010). Atmospheric Pollution Research 2014:5(3):438-446. https://doi.org/10.5094/APR.2014.051

[21] Venkitasamy S., Vijay Bhaskar B. Emission Inventory-A preliminary approach to primary pollutants. Current Science Association 2016:111(11):1831-1835. https://doi.org/10.18520/cs/v111/i11/1831-1835

[22] Mahesh S., Ramadurai G. Analysis of driving characteristics and estimation of pollutant emissions from intra-city buses. Transportation Research Procedia 2017:27:1211-1218. https://doi.org/10.1016/j.trpro.2017.12.071

[23] Mohan M., Dagar L., Gurjar B. R. Preparation and validation of gridded emission inventory of criteria air pollutants and identification of emission hotspots for megacity Delhi. Environmental Monitoring and Assessment 2007:130 323339. https://doi.org/10.1007/s10661-006-9400-9

[24] Baidya S., Borken-Kleefeld J. Atmospheric emissions from road transportation in India. Energy Policy 2009:37(10):3812-3822. https://doi.org/10.1016/j.enpol.2009.07.010

[25] Gurjar B.R., et al. Human health risks in megacities due to air pollution. Atmospheric Environment 2010:44(36):46064613. https://doi.org/10.1016/j.atmosenv.2010.08.011

[26] Mahadevappa H. A study on air pollution by automobiles in Bangalore city. Management Research and Practice (MRP) 2012:4(3):25-36.

[27] Singh R., Sharma C. Assessment of emissions from transport sector in Delhi. Journal of Scientific and Industrial Research 2012:71(2):155-160.

[28] Nagpure A. S., Sharma K., Gurjar B.R. Traffic induced emission estimates and trends (2000-2005) in megacity Delhi. Urban Climate 2013:4:61-73. https://doi.org/10.1016/j.uclim.2013.04.005

[29] National Green Tribunal. Compliance report before the national green tribunal principal bench, O.A. No 681 of 2018 New Delhi. New Dehli: NGT, 2018.

[30] Ghose M. K., Paul R., Banerjee S. K. Assessment of the impacts of vehicular emissions on urban air quality and its management in the Indian context: the case of Kolkata (Calcutta). Environmental Science and Policy 2004:7(4):345351. https://doi.org/10.1016/j.envsci.2004.05.004

[31] Das R., et al. Trace Element Composition of $\mathrm{PM}_{2.5}$ and $\mathrm{PM}_{10}$ from Kolkata - A Heavily Polluted Indian Metropolis. Atmospheric Pollution Research 2015:6(5):742-750. https://doi.org/10.5094/APR.2015.083

[32] Singh R., and Sharma, C., Agrawal, M. Emission inventory of trace gases from road transport in India. Transportation Research Part D: Transport and Environment 2017:52:64-72. https://doi.org/10.1016/j.trd.2017.02.011 
[33] Spiroska J., Rahman M. A., Pal S. Air pollution in Kolkata: An analysis of current status and interrelation between different factors. SEEU Review 2011:8(1):182-214. https://doi.org/10.2478/v10306-012-0012-7

[34] Census. Urban Agglomerations Census 2011. India. [Online]. [Accessed on 12.05.2020]. Available: https://www.census2011.co.in/urbanagglomeration.php

[35] Indiastat. Socio-economic statistical information about India, 2018. [Accessed 12.06.2020]. Available: http://www.indiastat.com/transport/30/vehicles/289/stats.aspx

[36] OGD. Open Government Data Platform. Government of India, 2018. [Accessed 02.08.2020]. Available: https://data.gov.in/search/site?query=transport\&filter\%5Bfield_group_name\%3Aname $\% 5 \mathrm{D}=\mathrm{Road}+$ Transport

[37] Ministry of Road Transport \& Highways. Road Transport Year Book (2011-12). New Dehli: MoRTH, 2012.

[38] IPCC. 2006 Guidelines for National Greenhouse Gas Inventories [Online]. [Accessed 16.02.2020] Available: https://www.ipcc-nggip.iges.or.jp/public/2006gl/

[39] Central Pollution Control Board. Status of pollution generated from road transport in six megacities ministry of environment, forest and climate change. New Delhi: CPCB, 2015.

[40] Ministry of Road Transport \& Highways. The Working Group Report on Road Transport for the Eleventh Five Year Plan, Planning Commission. New Dehli: MoRTH, 2007.

[41] ARAI Revision. The Automotive Research Association of India. Emission Factor Development for India Vehicles, Air Quality Monitoring Project-Indian Clean Air Programme, 2008. [Online]. [Accessed 28.10.2020]. Available: http://www.cpcb.nic.in/Emission_Factors_Vehicles.pdf

[42] Central Pollution Control Board. Transport fuel quality for the year 2005. New Dehli: CPCB, 2005.

[43] Mittal M. L., Sharma C. Anthropogenic emissions from energy activities in India: generation and source characterization. (Part II): emissions from Vehicular Transport in India. 2003.

[44] European Environment Agency. EMEP/CORINAIR Atmospheric Emission Inventory Guidebook. Copenhagen: EEA, 2001.

[45] Reynolds C. C. O., Grieshop A. P., Kandlikar M. Climate and health relevant emissions from in-use Indian threewheelers fuelled by natural gas and gasoline. Environmental Science and Technology 2011:45(6):2406-2412. https://doi.org/10.1021/es102430p

[46] Mashelkar R. A., et al. Report of the expert Committee on auto fuel policy. New Dehli: Ministry of Petroleum and Natural Gas, 2002.

[47] UNEP. Global environment outlook. London: Earthscan, 1999.

[48] Kandlikar M., Ramachandran G. The causes and consequences of particulate air pollution in urban India: a synthesis of the science. Annual Review of Energy and the Environment 2000:25(1):629-684. https://doi.org/10.1146/annurev.energy.25.1.629

[49] Dutta G., Dutta A. Indian growth story of automobile sector and atmospheric emission projection. Pollution Research 2018:37(1):131-143. 